\title{
O SDÍLENÍ ZKUŠENOSTÍ S MĚŘENÍM V KONTEXTU VÝZKUMNÉM I PSYCHODIAGNOSTICKÉM
}

\author{
MiROSLAV CHARVÁT \\ Katedra psychologie Filozofické fakulty Univerzity Palackého v Olomouci
}

\begin{abstract}
Abstrakt: V této úvaze se autor zamýšlí nad několika možnými důvody, které mohou brzdit a omezovat diskurz o měření v psychologii. Přestože rozličné psychodiagnostické metody a testy tvoří zcela zásadní a zatím bohužel jen obtížně nahraditelný zdroj informací jak pro psychology v praxi, tak pro ty ve výzkumu, jsou zkušenosti s jejich používáním, převodem či tvorbou v českém kontextu jen málo sdíleny. Mohou za to obavy, neznalost či nezájem? A co je možné udělat pro to, abychom to napravili?
\end{abstract}

Klíčová slova: psychometrika, tvorba a převod psychodiagnostických metod, měrení $v$ psychologii

\section{Úvod do problému}

V této úvaze se pokusím najít či rozkrýt důvody, proč je u nás v České republice nedostatek článků či původních studií věnujících se převodu a tvorbě metod či jejich standardizaci. Samozřejmě už tento první předpoklad může být mylný, nebot' podrobnou obsahovou analýzu českých ani zahraničních odborných časopisů věnujících se psychologii či př́buzným oborům jsem si nedělal. Jde spíše o domněnku založenou na vlastní zkušenosti a pozorování, a jako takovou ji budu dále prezentovat. Je i otázkou, co myslím tím, když používám slovo nedostatek. Samozřejmě vnímám a registruji, že řada článků v této oblasti vzniká, že mnohé výzkumné týmy tyto své zkušenosti sdílejí a psychometrické studie použitých metod publikují. Mám nicméně neodbytný dojem, že se toho $v$ této oblasti mezi kolegy $\mathrm{v}$ psychologickém výzkumu děje o dost více, než o čem je možné se dočíst. Problém vidím v tom, že své pozitivní ale i negativní zkušenosti s metodami, které si pro své potřeby vytváříme nebo častěji převádíme ze zahraničí, nesdílíme důsledně a dostatečně. Domnívám se, že zde působí jakási obdoba publikačního zkreslení zvaného „šuplíkový efekt“ (file drawer problem), jehož princip spočívá v nepublikování nezajímavých či nesignifikantních výsledků, což může vést k mylné generalizaci či přeceňování významu výsledků publikovaných studií (Rosenthal, 1979). Tento šuplíkový efekt v kontextu, o kterém píši, může v mnoha případech vést k dalšímu závažnému zkreslení, které se nazývá zkreslení metodou (test bias, method bias). Je to situace, kdy výsledky našeho výzkumu (například rozdíl mezi kontrolní 
a experimentální skupinou) nejsou způsobeny naší manipulací, ale jsou výsledkem špatné či nedokonalé konstrukce testu.

Častou příčinou deformace měřícího nástroje jsou například právě nepodařené adaptace z jiné jazykové verze. Vliv národního či kulturního kontextu na měření specifického psychologického konstruktu je vždy potřeba pečlivě prozkoumat, aby bylo možno metodu smysluplně přizpůsobit konkrétní kultuře. Je to proces poměrně náročný, nicméně z vědeckého hlediska zajímavý a určitě hodný samostatných výzkumných studií. Jak o tom podrobně píše např́íklad de Klerková (2008), důvodem k řešení problémů při mezikulturním testování (cross-cultural testing) je více. V psychodiagnostickém kontextu jde v první řadě o zajištění validního a férového měření v každé kultuře tak, aby nebyli znevýhodňováni lidé z odlišného sociokulturního prostředí. Ve výzkumném kontextu nám to také umožní realizaci srovnávacích studií např́ič kulturními a jazykovými skupinami tak, abychom zkoumané konstrukty měřili na stejné škále a nesrovnávali jablka s hruškami.

Z vlastní zkušenosti vím, že narazit na nějaké problémy s metodou není při skladbě výzkumné baterie vůbec žádnou výjimkou. Výzkumný tým může až časem objevit, že zvolená metoda se nechová tak, jak popisují zahraniční publikace. Vyjde nám například jiná faktorová struktura než u originálu; některé položky, přes veškeré snahy s několika verzemi překladu, stále nerozlišují; námi objevená škála se nechová jako jednodimenzionální, ačkoliv by měla atp. Samostatnou kapitolou tohoto problému, kterou chci jen vypíchnout, ale nebudu ji dále rozvádět, je tvorba norem testů. Tyto nedokonalosti často nejsou na první pohled patrné. Metoda může být špatně převedena, ale může být svým způsobem vadná už v originálním znění. Pokud o tom z nějakého důvodu nepodáme zprávu dál, mohou se do této pasti chytit další psychologové. Ještě horší situace může nastat, pokud si tuto chybu neuvědomíme a zdánlivě zajímavá data ve skutečnosti zatížená touto chybou následně publikujeme. To může mnohé dokonce nabádat k šíření této „zajímavé“ metody do praxe. Opatrnost je zde jistě na místě.

Co by nám mohlo výše popsané problémy a procesy usnadnit? Jednoznačně pozitivní přínos může mít právě sdílení těchto zkušeností, což se bohužel neděje v dostatečné míře. Napadá mě několik možných důvodů, proč tomu tak může být.

\section{Důvod první: obavy a strachy}

Bojíme se mluvit o obtížích, které nás při převodu a tvorbě provázejí. Můžeme mít obavy si přiznat (nebo přiznat kolegům), že se námi vybraná metoda nechová zcela spolehlivě nebo že měří něco trochu jiného, než má. A ono se to skutečně může zdát ohrožující pro naši odbornou pověst anebo pro náš výzkum. Mưžeme za to být kritizováni, může to velmi zdržet naše projekty. Možná je to dokonce ještě hlubší a spíše kolektivní problém. Psychologické měření je postaveno na velmi nestabilních základech, jak také naznačuje řada autorů, u nás např́íklad Urbánek, Denglerová, \& Širůček (2011). Bojíme se snad ještě více destabilizovat chatrný dojem stabilního a validního systému měření v našem oboru? Držet tyto problémy pod pokličkou nás ale nikam neposune. Pokud se autor či 
výzkumník přes tyto obavy přenese, očekával bych, že mu publikace př́ípadných nesrovnalostí a limitů přinese spíše úlevný efekt. Může mít „čisté svědomí“ v tom ohledu, že o kvalitě a potenciálu svých výzkumných nástrojů podal ucelenou zprávu. Když si navíc bude moci na základě přečtení podobných článku od kolegů říci: „,...aha, tak oni to taky řešili, jim to taky nevyšlo, oni to zkusili takto...", pak se celkově ještě více uvolní napětí kolem této stále málo diskutované slabiny psychologie jako vědy. Pak se mohou začít snáze rodit nové recepty, jak měření psychologických „veličin“ zlepšit. V psychodiagnostické praxi tomuto procesu mohou velmi napomoci i recenze jednotlivých metod v evropském formátu dle EFPA, jak o tom podrobně píše Urbánek (2013).

\section{Důvod druhý: neznalost postupů}

Neumíme to, nevíme jak na to, určité dovednosti jsme si zatím neosvojili. Zejména u psychometrických postupů, často postavených na specifických statistických či matematických principech, se nám jejich osvojení jako psychologům jeví z nějakého důvodu jako obtížnější, než ve skutečnosti je. Připomíná mi to situace typické při obhajobách kvalifikačních diplomových prací, během kterých se někteří studenti snaží co nejrychleji přeskočit od teoretické části práce rovnou po prezentaci výsledků $\mathrm{s}$ jakýmsi skrytým odporem $\mathrm{k}$ metodologii. Při popisu těchto pro mě klíčových pasáží, jsou mnohdy až př́liš struční nebo zrychlí tempo prezentace a už, už aby to bylo za nimi. Toto lze shovívavě odpustit „učedníkům“ ale u akademikủ či praktiků bych už zájem o hlubší pochopení konstrukce metod spíše vyžadoval. V tomto momentu se zde často nabízí zdánlivě elegantní ale poměrně nebezpečná př́ležitost, a sice delegovat tyto nepohodlné kroky na někoho zkušeného, na specialisty, na statistiky, metodology či psychometriky. Delegování může uspokojivě fungovat, pouze pokud se tento expert stane integrální součástí týmu a budeme s ním moci diskutovat o našich výsledcích na opravdu pravidelné bázi. To znamená, že za asistence tohoto experta pronikneme do psychometrické podstaty věci a můžeme se pak s danou znalostí pustit do přiměřených intepretací získaných dat. Jinak hrozí oddělení měření od vlastního uchopování výsledků a zkoumaných jevů. Spíše zavrženíhodné je pak praktikovat vyhodnocování dat „na dálku“, kdy za nás vše vyřeší jakási černá skř̌iňka či vzdálené cloudové řešení. Poměrně názorným př́kladem zneužití tohoto řešení a sním spojených rizik je kritizovaná metoda Barva života (Cígler, 2013).

Jinými slovy, psychometrické minimum by mělo patřit do základní výbavy každého výzkumníka i praktika. Toto si samozřejmě plně uvědomovali i tvůrci modelového kurikula v oboru psychologie, když v evropském kontextu definovali koncepci EuroPsycholog (EFPA, 2008), kde se to metodologickými a psychometrickými dovednostmi jen hemží. Tento problém nedostatečné psychometrické průpravy může být ještě širší a může mít ještě větší důsledky, když si ho spojíme s trendem etablujících se semiprofesí a přesunem některých diagnostických činností mimo profesní rámec psychologie např́klad na pedagogy, jak o tom píše Mareš (2013). 


\section{Důvod třetí: nedostatek zájmu}

Tématu se nebojíme, něco o psychometrice i víme, ale nemáme na to čas. Publikování článků o metodách pro nás není primárním cílem. Metody jsou jen prostředkem pro naše výzkumné cíle a jejich standardizace není sama o sobě pro nás nijak vědecky zajímavá. Spíše se jedná o komplikaci. Pokud je převádíme ze zahraničí či přetváříme, tak jen z nouze. Jiné podobné metody, které by měřily náš kýžený konstrukt, nebo které by odpovídaly našemu teoretickému ukotvení, totiž nejsou k dispozici v českém jazyce nebo vůbec. Tento důvod je asi nejzrádnější, protože se nejedná o obavu, kterou lze rozptýlit, nejedná se ani o neznalost, kterou lze doučit. Jde o motivaci. Čas si najdeme vždy na to, co je pro nás důležité. Vnímání důležitosti je ale velmi individuální. Může nám být tak trochu jedno, jak moc jsou metody reliabilní, objektivní, validní či standardizované: „...však oni ty testy něco nějak změří, každý je přeci nějak používá, tak proč se s tím trápit“. Zde ale narážíme na etický problém. Namísto podrobné analýzy si tento argument dovolím odbít jen odkazem na jeden základní princip. Nasnadě je etický požadavek vědecké přísnosti ve výzkumu (scientific rigour), který definuje například etický metakodex Evropské federace psychologických asociací (Meta-code of Ethics; EFPA, 2005). Příprava výzkumného sdělení podle něj předpokládá (mimo jiné) odbornou kompetenci psychologa, tj. jeho analytickou a interpretační zkušenost. $\mathrm{V}$ kontextu aplikované psychodiagnostiky, např. v klinické psychologii, pak najdeme jistě mnoho dalších odkazů na nutnost používání kvalitních a prověřených nástrojů.

Dalším argumentem může být, že když už někdo metodu vydal, je to jeho odpovědnost. Jistě, že se můžeme částečně spolehnout na distributory metod, že za nás určitou práci udělají, nicméně i ti se mohou dopustit chyb. Na kontrolu kvality psychodiagnostických metod nemohou všichni rezignovat. Někdo musí na stráži stát. Důsledky, které by nestandardizované či nevalidní metody mohly přinést a vlastně již přinášejí do života lidí, jsou v kontextu oboru psychologie až děsivé, když se nad tím zamyslíme. Ve výzkumu zas nepřesné nástroje určitě nepřinesou mnoho vhledu do zkoumaných problémů. To znamená, že pokud nám jde o kvalitu, nemůžeme na psychometrické kvality metod zapomínat ani jejich ověřování převádět někam na druhou kolej. Musíme se smířit s tím, že žijeme v poměrně malém jazykovém a kulturním prostředí, a že tudíž prvním nutným krokem mnoha výzkumů bude právě standardizace vhodných psychodiagnostických metod. Ten, kdo už tímto procesem prošel, ví, že je to náročné a možná v duchu zvažuje, zda chce tuto náročnou zkušenost ještě někdy opakovat. Možná že poctivě převedených metod bude méně, než bychom si představovali. $V$ tom prrípadě je nutná lepší selekce, musíme si umět lépe vybrat, která metoda skutečně stojí za to. Vyhnout se tomuto kroku ale dle mého názoru nelze. Na druhou stranu i tato fáze může přinést cenné akademické body, když se naučíme o ni referovat v odborném tisku a na odborných fórech. Je i chybou systému, že podobné aktivity více nepodporuje a že např́íklad manuál k psychodiagnostické metodě nemusí být brán jako plnohodnotný a bodovaný akademický výstup. 


\section{Důvod čtvrtý: publikace v zahraničí a v impaktovaných časopisech}

Neplatí v zásadě žádný z předchozích důvodů, tj. psychometriku nepodceňujeme, nebojíme se o ni psát, ani nám to není zatěžko. Proč bychom o tom ale publikovali česky, když se nabízí řada př́ležitostí $v$ impaktovaných či recenzovaných zahraničních časopisech. Tak to je asi jediný důvod mnou vnímané nízké četnosti odborných článků s psychometrickou tématikou, který nemám potřebu nějak moc vyvracet nebo na něj spílat. Napadá mě snad jen ten drobný fakt, že mnoho lidí si o metodách raději přečte v češtině. To ale narážíme bud' na jazykové kompetence, které jsou tématem na samostatnou úvahu, nebo opět na motivaci věnovat něčemu trochu více času. Samozřejmě že bych byl jako člen redakční rady časopisu Testfórum rád, aby se mnoho článků at' už v jakémkoliv jazyce přicházelo právě do naší redakce. Taky v to do budoucna doufám. Důvody by se našly: poctivé recenze, vše na jednom místě, online a zdarma př́stup k fulltextům, ale to už se mi tato úvaha zvrhává ve sprostou reklamu.

\section{Povzbuzení závěrem}

Přestože může tato úvaha vyznívat jako kárající, zamýšlel jsem ji spíše jako motivační. Domnívám se, že všechny ze jmenovaných důvodů lze překonat. Obavy lze rozptýlit, postupy se lze naučit, čas na důležité věci se dá nalézt. Psychodiagnostické metody jistě patří mezi to, co by se dalo nazvat rodinným stř́ibrem psychologie. Máme je rádi a snažíme se si je chránit, tak proč bychom je neměli více tříbit a cizelovat. Přestože jsem povětšinou psal o kontextu výzkumném, přesah této problematiky do diagnostické praxe je též více než zřejmý. Publikujme proto o metodách, o našich pozitivních ale zejména pak i negativních zkušenostech s nimi, nebo nám pomalu ale jistě odumře celý obor psychologie. Zhyne na chorobu z nepřesného měření a bude nemilosrdně vytěsněn jinými vědními disciplínami. Já si to nepřeji. Vy ano? Nebo se vám nezdá, že je situace tak kritická? Vidíte i jiné souvislosti a příčiny problémů s měřením v našem oboru? Pojd'me o tom diskutovat.

\section{Literatura:}

Cígler, H. \& Mafková, J. (2013). Metoda barvově-slovních asociací (takzvané Barvy života) není diagnostickým nástrojem. TESTFÓRUM, 2013(2), 28-31

EFPA (2005). Meta-Code of Ethics. Získáno 19. 1. 2014 z: http://www.efpa.eu/ethics/ethicalcodes EFPA (2008). Europsycholog - Evropský certifikát pro psychologii. Praha: Grada.

de Klerk, G. (2008). Cross-cultural testing. In M. Born, C.D. Foxcroft \& R. Butter (Eds.), Online Readings in Testing and Assessment, International Test.

Mareš, J (2013). Pedagogicko-psychologická diagnostika jako zadní dvorek psychologické diagnostiky? TESTFÓRUM, 2013(2), 28-31

Rosenthal, R. (1979). The file drawer problem and tolerance for null results. Psychological Bulletin 86 (3): 638-641. doi:10.1037/0033-2909.86.3.638.

Urbánek, T., Denglerová, D., Širůček, J. (2011). Psychometrika: měření v psychologii. Praha: Portál.

Urbánek, T. (2013). Hodnocení kvality psychodiagnostických metod ve světě a u nás. TESTFÓRUM, 2013(2), 28-31 
Podpořeno z projektů OPVK:

SOVA-21 - Internacionalizace, inovace, praxe: sociálně-vědní vzdělávání pro 21. století, CZ.1.07/2.2.00/28.0225

INZA - Inovací bakalářských studijních programů k lepší zaměstnatelnosti,

CZ.1.07/2.2.00/28.0238

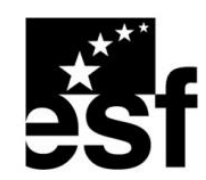

INVESTICE DO ROZVOJE VZDĚLÁVÁNI

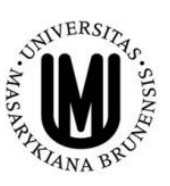

